\title{
Growth Promoting Effect of Dietary Urea and Diammonium Citrate in the Chick
}

\author{
Jun-ichi Okumura and Katsutoshi Kino \\ Laboratory of Animal Nutrition, Faculty of Agriculture \\ Nagoya University, Nagoya-shi 464
}

Since Rose $e t$ al. ${ }^{1)}$ observed that dietary ammonium salts and urea markedly improved the growth of rats fed a diet containing only essential amino acids, the use of non-protein nitrogen (NPN) source for poultry has been much studied, but the results of these studies are inconsistent. Sullivan and BIRD ${ }^{2}$ found that the chick could use diammonium citrate (DAC) and urea when fed low protein diets containing adequate amounts of essential amino acids. Featherstone et $\mathrm{al}{ }^{3)}$ were able to show that chicks fed a diet including all the essential amino acids could utilize supplemented dietary urea and DAC to achieve growth, although possibly not as efficient as that achieved by the inclusion of dispensable amino acids in the diet. Young et al. ${ }^{4}$ ) reported that with laying hens, addition of DAC at $3 \%$ protein equivalent to a $13 \%$ protein diet increased egg production to a level achieved with a $16 \%$ protein diet. Several other investigators were also able to demonstrate the utilization of urea and DAC by poultry (Blair et al. ${ }^{5}$ ), LeE and Blair ${ }^{6}$ and Allen and BaKer ${ }^{7}$ ).

In contrast, there are a number of reserches reporting no utilization of urea and DAC by poultry. Moran et al. ${ }^{8)}$ found that using a $10 \%$ protein diet in combination with either urea or DAC at a level of $5 \%$ protein equivalent, the supplements were ineffective for growth and proved to be toxic when the nitrogen was in the form of DAC. BaLloun and KAZEMI ${ }^{9}$, Trakulchang and Balloun ${ }^{10)}$ and Nathanael et al. ${ }^{11)}$ also failed to demonstrate with growing chicks that the addition of urea or DAC to a low protein diet improve body weight gain or feed conversion.

The purpose of the present study was to compare the growth response of chicks to varying levels of supplemented urea, DAC and L-glutamic acid.

\section{Materials and Methods}

One-day-old Single Comb White Leghorn male chicks were housed in electrically-heated battery brooders. They received a proprietary commercial chick diet for 7 days. On day 8 the chicks were individually weighed after fasting for $2 \mathrm{~h}$ and were then selected and assigned to 16 groups of four chicks each and a control group of six chicks in such a way that the weight distribution was uniform for each group. And one of the groups of four chicks was killed for the determination of initial body composition. At this stage they were housed individually in metabolism cages and fed on the appropriate experimental diets ad libitum from day 8 to day 18 .

Table 1 shows the composition of the basal diet which was designed to contain all the essential amino acids at an adequate level, but except for non-essential amino acids. Table 
Table 1. Composition $(\mathrm{g} / \mathrm{kg})$ of basal diet

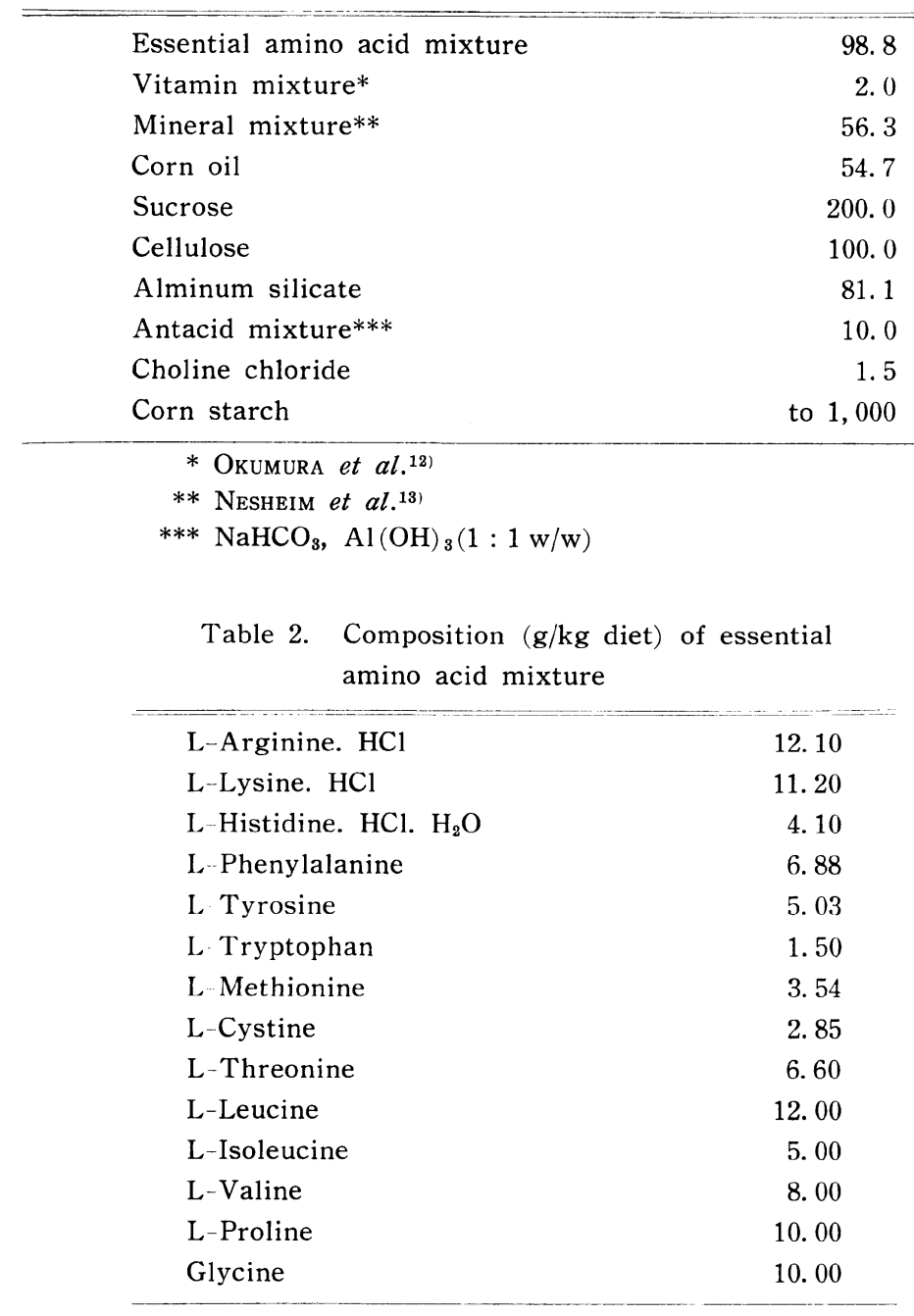

2 gives the composition of an essential amino acid mixture (containing $14.25 \mathrm{~g}$ nitrogen ( $\mathrm{g}$ $\mathrm{N})$ ). In this study glycine and L-proline were included in the mixture as essential amino acids for chicks. Fifteen other diets were made by supplementing 3.17, 6.35, 9.52, 12.69 and $15.87 \mathrm{~g} \mathrm{~N}$ of urea, DAC and glutamic acid, respectively, to the basal diet at the expense of corn starch. The amount of $9.52 \mathrm{~g} \mathrm{~N}$ for urea, DAC and glutamic acid correspond to $30.6,76.8$ and $100.0 \mathrm{~g}$, respectively, and $100 \mathrm{~g}$ glutamic acid $/ \mathrm{kg}$ diet is a requirement of non-essential amino acid for the chick (OKUMURA and Kino, unpublished).

The chicks were weighed and food intake was measured on alternate days. At the end of the experiment all chicks were killed for carcass analysis.

Carcasses were deep frozen and minced with a meat grinder. The minced carcasses were deep frozen again with solid carbon dioxide and minced again. The mince was dried at $55^{\circ} \mathrm{C}$ for $48 \mathrm{~h}$, then finely ground. Total nitrogen in the diets and carcasses was determined by Kjeldahl method and carcass protein was defined as $N \times 6.25$. Carcass fat was extracted overnight (about $16 \mathrm{~h}$ ) with diethyl ether using a Soxhlet apparatus and determined 
gravimetrically. Gains in protein and fat during the experimental period were estimated by subtracting the initial values of body composition from the final ones. Energy retention was computed from fat and protein retention using the values of $23.68 \mathrm{~kJ} / \mathrm{g}$ for body protein and $39.12 \mathrm{~kJ} / \mathrm{g}$ for body fat $\left(\right.$ FRAPS $\left.^{(4)}\right)$.

Analysis of variance was used to analyze the data statistically and the mean differences for two-way comparison were evaluated by Student's $t$-test. For comparison of more than two means, the Duncan's multiple range test was applied (Duncan $\left.{ }^{15}\right)$. The linear regression curves in nitrogen retention of chicks were estimated according to the method of SNEDECOR and CochraN ${ }^{16)}$. As fitting an exponential function, interative non-linear least square method was used and for this model the response which reached more than $95 \%$ of the response from lowest dose to upper asymptote was regarded as maximum one.

\section{Results}

Table 3 shows the effect of dietary supplementation with urea, DAC and glutamic acid as a non-essential nitrogen source on body weight gain, food intake and gain : food ratio of chicks. Dietary supplementation with urea increased body weight gain and food intake, and except for body weight gain at the level of $9.52 \mathrm{~g} \mathrm{~N} / \mathrm{kg}$ diet these values were significantly higher than those of the chicks fed the basal diet, at the levels beyond $6.35 \mathrm{~g} \mathrm{~N} / \mathrm{kg}$ $\operatorname{diet}(\mathrm{P}<0.05)$. Gain : food ratio was also improved, however, this effect did not reach statistical significance. With the increase of dietary DAC, the performance increased until the level of $6.35 \mathrm{~g} \mathrm{~N} / \mathrm{kg}$ diet and thereafter tended to decline. And at the levels of 3.17 , 6.35 and $9.52 \mathrm{~g} \mathrm{~N} / \mathrm{kg}$ diet, they were significantly higher than those of the basal diet $(\mathrm{P}<$ 0.01). Dietary supplementation with glutamic acid resulted in a significant improvement in the performance at all dietary levels $(\mathrm{P}<0.01)$. As dietary glutamic acid increased, body weight gain and gain : food ratio increased until the level of $9.52 \mathrm{~g} \mathrm{~N} / \mathrm{kg}$ diet at which point plateau occured but food intake did not significantly change above $3.17 \mathrm{~g} \mathrm{~N} / \mathrm{kg}$ diet.

Table 3. Effect of graded levels of urea, diammonium citrate (DAC) and glutamic acid (Glu) on body weight gain, food intake and gain : food ratio in chicks (values are means of each group for a period of 8 to 18 days of age)

\begin{tabular}{|c|c|c|c|c|c|c|c|c|c|}
\hline \multirow{3}{*}{$\begin{array}{c}\text { Levels of non-essential } \\
\text { nitrogen } \\
\text { (g N/kg diet) } \\
0.00\end{array}$} & \multicolumn{3}{|c|}{$\begin{array}{l}\text { Body weight gain } \\
(\mathrm{g})\end{array}$} & \multirow{2}{*}{\multicolumn{3}{|c|}{$\begin{array}{c}\text { Food intake } \\
(\mathrm{g}) \\
124.8^{\mathrm{A}}\end{array}$}} & \multirow{2}{*}{\multicolumn{3}{|c|}{$\begin{array}{c}\begin{array}{c}\text { Gain : food } \\
\text { ratio }\end{array} \\
0.263^{\mathrm{A}}\end{array}$}} \\
\hline & \multicolumn{3}{|c|}{$33.2^{\mathrm{aA}}$} & & & & & & \\
\hline & Urea & DAC & Glu & Urea & DAC & Glu & Urea & $\mathrm{DAC}$ & Glu \\
\hline 3.17 & $42.7^{\mathrm{ab} *}$ & $60.3^{\mathrm{BC}}$ & $69.3^{\mathrm{B}}$ & 141. $3 \mathrm{AB} *$ & $164.8 \mathrm{C}$ & 184. $0^{\mathrm{B}}$ & $0.300^{*}$ & $0.365^{\mathrm{B}}$ & $0.379^{\mathrm{B}}$ \\
\hline 6.35 & $51.0^{\mathrm{b}}$ & $65.8 \mathrm{C}$ & $77.3^{\mathrm{BC}}$ & 159. $3^{\mathrm{B}}$ & $167.3^{\mathrm{C}}$ & $178.5^{\mathrm{B}}$ & 0.321 & $0.394^{\mathrm{B}}$ & $0.435^{\mathrm{BC}}$ \\
\hline 9.52 & $39.5^{\mathrm{ab}}$ & $57.5^{\mathrm{BC}}$ & $91.0 \mathrm{C}$ & $147.8 \mathrm{AB}$ & 148. $5^{\mathrm{BC}}$ & $191.3^{\mathrm{B}}$ & 0.266 & $0.381^{\mathrm{B}}$ & $0.476 \mathrm{c}$ \\
\hline 12.69 & $49.0^{\mathrm{b}}$ & $42.3^{\mathrm{AB}}$ & $86.3^{\mathrm{c}}$ & 158. $0^{\mathrm{B}}$ & 134. $5^{\mathrm{AB}}$ & $176.5^{\mathrm{B}}$ & 0.309 & $0.312^{\mathrm{AB}}$ & $0.490 \mathrm{C}$ \\
\hline 15.87 & $48.5^{\mathrm{b}}$ & $41.8 \mathrm{AB}$ & $84.0 \mathrm{BC}$ & $156.8^{\text {в }}$ & $122.8^{\mathrm{A}}$ & 173. $0^{\mathrm{B}}$ & 0.310 & $0.338 \mathrm{AB}$ & $0.486^{\mathrm{C}}$ \\
\hline Pooled SEM & 4.4 & 3.8 & 2.8 & 7.1 & 6.5 & 5.5 & 0.015 & 0.020 & 0.022 \\
\hline
\end{tabular}

For the unsupplemented group 6 chicks, and for the other groups 4 chicks were used. Effects of dietary levels were evaluated for each nitrogen compound and values having different superscript are significantly different $(A, B, C ; P<0.01, a, b ; P<0.05)$. Residual mean square for body weight gain, food intake and gain : food ratio were 58.2,183.4 and $1,495 \times 10^{-6}$, respectively. *One missing value. 


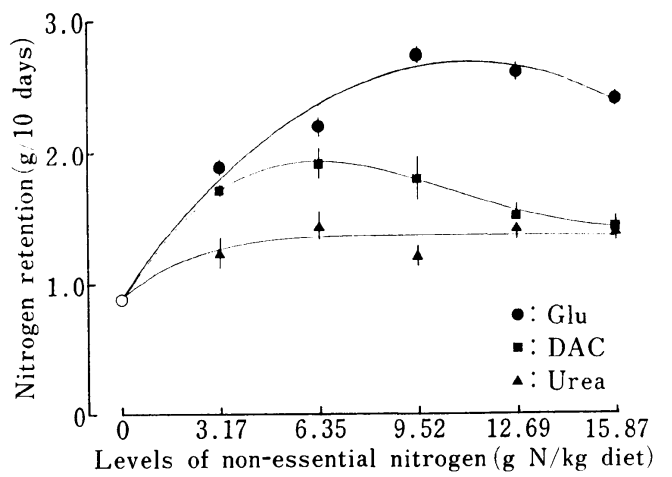

Fig. 1. Nitrogen retention of chicks fed graded levels of urea, diammonium citrate (DAC) and glutamic acid (Glu).

Figure 1 shows the nitrogen retention of the chicks fed graded levels of urea, DAC and glutamic acid. At all dietary levels, addition of these nitrogen compounds to the basal diet resulted in a significant increase in nitrogen retention $(\mathrm{P}<0.05)$. Nitrogen retention of the chicks fed the diet containing urea above the level of $3.17 \mathrm{~g} \mathrm{~N} / \mathrm{kg}$ diet did not change significantly, and at all dietary levels it was significantly lower as compared with that of chicks offered the diet with glutamic acid $(\mathrm{P}<0.01)$. Similar to the growth data, nitrogen retention of the chicks given the diet with DAC increased until the level of $6.35 \mathrm{~g} \mathrm{~N} / \mathrm{kg}$ diet with the increase of dietary DAC level and thereafter declined. At the levels of 3.17 and $6.35 \mathrm{~g} \mathrm{~N} / \mathrm{kg}$ diet, there was not observed significant difference between the effects of DAC and glutamic acid supplementation on nitrogen retention of chicks, whereas at the levels beyond $6.35 \mathrm{~g} \mathrm{~N} / \mathrm{kg}$ diet, the nitrogen retention of the chicks given DAC were significantly lower than that of the chicks given glutamic acid.

The regression equations which indicate the relationship between nitrogen retention of

Table 4. Effect of graded levels of urea, diammonium citrate (DAC) and glutamic acid $(\mathrm{Glu})$ on enegy retention and retention rate of nitrogen and energy (values are means of each group for a period of 8 to 18 days of age)

Levels of non-essential nitrogen (g N/kg diet)

0.00

3. 17

6. 35

9.52

12. 69

15. 87

Pooled SEM
Energy retention $(\mathrm{kJ})$ $436^{\mathrm{a} A C}$ Urea

\begin{tabular}{llr}
\multicolumn{1}{c}{ rea } & DAC & Glu \\
$551^{\text {abc } *}$ & $753^{\mathrm{D}}$ & $839^{\mathrm{B}}$ \\
$685^{\mathrm{c}}$ & $763^{\mathrm{D}}$ & $831^{\mathrm{B}}$ \\
$504^{\text {ab }}$ & $568^{\mathrm{CD}}$ & $883^{\mathrm{B}}$ \\
$611^{\text {bc }}$ & $378^{\mathrm{AC}}$ & $754^{\mathrm{B}}$ \\
$640^{\text {bc }}$ & $295^{\mathrm{A}}$ & $802^{\mathrm{B}}$
\end{tabular}

Retention rate

Nitrogen

$0.445^{\mathrm{ACD}}$

Urea DAC Glu

$0.438^{\mathrm{A} *} \quad 0.548^{\mathrm{D}} \quad 0.535^{\mathrm{AB}}$

$0.386^{\mathrm{AB}} \quad 0.528 \mathrm{CD} \quad 0.565^{\mathrm{AB}}$

$0.310^{\mathrm{B}} \quad 0.484^{\mathrm{ACD}} 0.585^{\mathrm{B}}$

$0.298 \mathrm{~B}$

$0.263^{\mathrm{B}}$

0.029

$0.408 \mathrm{AC} \quad 0.532^{\mathrm{AB}}$

$0.382^{\mathrm{A}}$

$0.450 \mathrm{~A}$

0. 030

0.030

48

For the unsupplemented group 6 chicks, and for the other groups 4 chicks were used. Effects of dietary levels were evaluated for each nitrogen compound and values having different superscript are significantly different (A, B, C, D; $\mathrm{P}<0.01$, a, b, c; $\mathrm{P}<0.05)$. Residual mean square for energy retention and retention rate of nitrogen and energy were $8,437,2,654 \times 10^{-6}$ and $1,715 \times 10^{-6}$, respectively. *One missing value. 
the chicks fed urea (NRu, g/10 days), DAC (NRD, g/10 days) and glutamic acid (NRG, $\mathrm{g} / 10$ days) and dietary level of each nitrogen compound were estimated as follows:

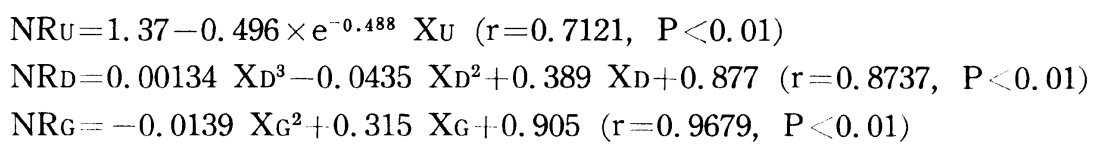

where $\mathrm{XU}_{\mathrm{U}}, \mathrm{XD}_{\mathrm{D}}$ and $\mathrm{XG}_{\mathrm{G}}$ are the dietary nitrogen level $(\mathrm{g} \mathrm{N} / \mathrm{kg}$ diet) of urea, DAC and glutamic acid, respectively. From these equations the dietary level (g N/kg diet) of urea above which and the levels of DAC and glutamic acid at which, chicks can retain nitrogen most are 6.13, 6.27 and 11.3, respectively.

Table 4 shows the energy retention and retention rate of nitrogen and energy of the chicks. As dietary urea increased nitrogen retention rate decreased and above the level of $9.52 \mathrm{~g} \mathrm{~N} / \mathrm{kg}$ diet, it was significantly lower than that of the basal diet $(\mathrm{P}<0.01)$. Improvement in the nitrogen retention rate was noted for the addition of DAC at the levels of $3.17,6.35$ and $9.52 \mathrm{~g} \mathrm{~N} / \mathrm{kg}$ diet, but with the increase of dietary DAC beyond $3.17 \mathrm{~g} \mathrm{~N} /$ $\mathrm{kg}$ diet the rate was decreased. In contrast, for the increase of dietary glutamic acid up to $6.35 \mathrm{~g} \mathrm{~N} / \mathrm{kg}$ diet, a progressional response in the nitrogen retention rate was noted and at this level chicks could utilize nitrogen for the growth with the highest efficiency. Retention and retention rate of energy of the chicks fed the diets supplemented with urea and DAC had a similar trend as body weight gain and nitrogen retention. Supplementation with glutamic acid significantly increased retention $(\mathrm{P}<0.01)$ and retention rate of energy $(\mathrm{P}<$ $0.05)$, although any further improvement was not observed at the levels beyond $3.17 \mathrm{~g} \mathrm{~N} /$ $\mathrm{kg}$ diet.

\section{Discussion}

The present result shows that dietary inclusion of urea or DAC has a growth promoting effect in chicks. The utilization of these compounds by poultry has been a subject of controversy for many years. Most of workers who showed negative responses used diets containing low intact proteins as a basal diet. In the present study crystalline amino acid diets were used in the same way as the studies of Featherstone et al. ${ }^{3)}$, Blair et al. ${ }^{5}$, LeE and BLAIR $^{6)}$ and Allen and BAKER ${ }^{7)}$ who indicated significant utilization of NPN by chicks. BLAIR et al. ${ }^{5)}$ suggested that nitrogen from ammonium compounds and urea is only likely to be useful in satisfying the non-essential amino acid requirement of the bird and therefore using the diet which contains a balanced sufficiency but not excess of essential amino acids, together with a deficiency of non-essential amino acids maximize the utilization of such nitrogen compounds.

In the present study, dietary supplementation with urea increased body weight gain and nitrogen retention but beyond $3.17 \mathrm{~g} \mathrm{~N} / \mathrm{kg}$ diet any significant improvement in the performance was not observed. Using the diets supplemented with incremental levels of $1.03 \%$ urea from zero to $6.18 \%$, OKumura et al. ${ }^{17)}$ reported that body weight gain and nitrogen retention of the chicks curvilinearly increased with the urea supplemented up to $5.15 \%$, but no statistical significant difference was noted between dietary levels of urea from 1.03 to $6.18 \%$. The importance of micro-organism in the utilization of urea by chicks was studied by Oкumura et al. ${ }^{12)}$ comparing the effectiveness of supplemented urea in germ-free and 
conventional chicks and they concluded that the micro-organisms are responsible for the growth promoting effect of urea, presumably through the release of ammonia by bacterial urease and its consequent incorporation into amino acids. Moreover OKUmURA et al. ${ }^{18)} \mathrm{dem}$ onstrated ${ }^{15} \mathrm{~N}$ of dietary ${ }^{15} \mathrm{~N}$ labelled urea was incorporated into the body tissue proteins of the chicks. However, the present study did not support clearly that chick could utilize urea as non-essential nitrogen source and suggested that the growth promoting effect of urea mainly caused from increased food intake.

The effect of dietary supplementation with DAC on chick growth was varied with its dietary level. Body weight gain and nitrogen retention of the chicks increased with the increase of dietary DAC level until the level of $6.35 \mathrm{~g} \mathrm{~N} / \mathrm{kg}$ diet and thereafter tended to decline. Growth promoting effect of DAC under the level of $6.35 \mathrm{~g} \mathrm{~N} / \mathrm{kg}$ diet was comparable to that of glutamic acid. ALLEN and BAKER ${ }^{7)}$ also reported that addition of DAC at the level of 1.54 or $3.08 \%$ gave similar response as that of glutamic acid, and that using slope ratio technique, growing chicks fed the diet supplemented with DAC utilized it for body weight gain and protein retention with efficacy of 86.6 and $74.3 \%$, respectively, setting Lglutamic acid at $100 \%$ efficacy.

LEE and BLAIR $^{6}$ assessed the relative effectiveness of monoammonium citrate (MAC), DAC and triammonium citrate (TAC) as a replacement for glutamic acid and indicated MAC caused a growth depression while TAC gave the best performance. Since these ammonium salts were supplemented to the diets isonitrogenously, the diets differed in citrate level; the diet with MAC contained most in contrast to the diet with TAC which contained least. Therefore, they discussed citrate level may be a factor in determining the growth rate. In this experiment, the effect of citrate level on chick growth was not investigated but in studing utilization of ammonium citrate, it seems to be necessary to study further the effect of dietary citrate on chick growth.

\section{Summary}

The experiment was conducted to compare the growth response of chicks to varying levels of supplemented urea, diammonium citrate (DAC) and L-glutamic acid. The chicks were fed the amino acid diets which contained all essential amino acids at their requirements and were supplemented with urea, DAC and glutamic acid as a non-essential nitrogen source at the levels of $3.17,6.35,9.52,12.69$ and $15.87 \mathrm{~g} \mathrm{~N} / \mathrm{kg}$ diet, respectively. As dietary level of urea increased, body weight gain and nitrogen retention increased until the level of $6.35 \mathrm{~g} \mathrm{~N} / \mathrm{kg}$ diet and beyond this level no further improvement in the performance was not observed. Above the level of $6.35 \mathrm{~g} \mathrm{~N} / \mathrm{kg}$ diet body weight gain and nitrogen retention were significantly higher than those of the basal diet except for body weight gain at the level of $9.52 \mathrm{~g} \mathrm{~N} / \mathrm{kg}$ diet, whereas they were significantly inferior to those of glutamic acid at all dietary levels. With the increase of dietary DAC, body weight gain and nitrogen retention increased until the level of $6.35 \mathrm{~g} \mathrm{~N} / \mathrm{kg}$ diet and thereafter decreased by the inhibitory effect which presumably responsible for dietary citrate level on chick growth. At the levels of $3.17,6.35$ and $9.52 \mathrm{~g} \mathrm{~N} / \mathrm{kg}$ diet the performance of chicks was significantly improved as compared to that of the basal diet, and growth promoting effect of DAC under the level of $6.35 \mathrm{~g} \mathrm{~N} / \mathrm{kg}$ diet was comparable to that of glutamic acid. From the regression 
curves the dietary level ( $\mathrm{g} \mathrm{N} / \mathrm{kg}$ diet) of urea above which and the levels of DAC and glutamic acid at which, chicks could retain nitrogen most, were $6.13,6.27$ and 11.3, respectively.

\section{References}

1) Rose, W. C., L. C. Smith, M. Womack and M. Shane (1949) The utilization of the nitrogen of ammonium salts, urea, and certain other compounds in the synthesis of non-essential amino acids in vivo: J. Biol. Chem., 181: 307-316.

2) Sullivan, T. W. and H. R. Bird (1957) Effect of quantity and source of dietary nitrogen on the utilization of the hydroxy analogues of methionine and glycine by chicks: J. Nutr., 62: 143-150.

3) Featherstone, W. R., H.R. Bird and A.E. Harper (1962) Effectiveness of urea and ammonium nitrogen for the synthesis of dispensable amino acids by the chick: J. Nutr., 78: 198-206.

4) Young, R. J., M. Griffith, I. D. Desai and M. L. Scott (1965) The response of laying hens fed low protein diets to glutamic acid and diammonium citrate: Poultry Sci., 44: 1428.

5) Blair, R., D. W. F. Shannon, J. M. McNab and D. J. W. Lee (1972) Effects on chick growth of adding glycine, proline, glutamic acid or diammonium citrate to diets containing crystalline essential amino acids: Br. Poultry Sci., 13: 215-228.

6) LEE, D. J. W. and R. BLAIR (1972) Effects on chick growth of adding various non-protein nitrogen source or dried autoclaved poultry manure to diets containing crystalline essential amino acids: $\mathrm{Br}$. Poultry Sci., 13: 243-249.

7) Allen, N.K. and D. H. Baker (1974) Quantitative evaluation of nonspecific nitrogen sources for the growing chick: Poultry Sci., 53: 258-264.

8) Moran, E. T., J. D. Summers and W. F. Pepper (1967) Effect of non-protein nitrogen supplementation of low protein rations on laying hen performance with a note on essential amino acid requirements: Poultry Sci., 46: 1134-1144.

9) Balloun, S. L. and R. Kazfmi (1974) Growth inhibition of broilers by diammonium citrate: Poultry Sci., 54: 307-309.

10) Trakulchang, N. and S. L. Balloun (1975) Nonprotein nitrogen for growing chickens: Poultry Sci., 54: 591-594.

11) Nathanael, A., A. Kagan and S. L. Balloun (1976) Effects of diammonium citrate in practical-type broiler diets: Poultry Sci., 55: 1158-1160.

12) Okumura, J., D. Hewitt, D. N. Salter and M. E. Coates (1976) The role of the gut microflora in the utilization of dietary urea by the chick: Br. J. Nutr., 36: 265-272.

13) Nesheim, M.C., J. D. Garlich and D. T. Hopkins (1962) Studies on the effect of raw soybean meal on fat absorption in young chicks: J. Nutr., 78: 89-94.

14) Fraps, G.S. (1946) Composition and productive energy of poultry feeds and rations: Texas Agriculture Station. Bulletin, 678: 1-37.

15) Duncan, D. B. (1955) Multiple range and multiple F tests: Biometrics, 11: 1-42.

16) Snedecor, G. W. and W. G. Cochran (1980) Stastical Methods, 7th Ed. : Iowa State Univ. Press: 393-413.

17) Okumura, J., H. Tanaka and T. Muramatsu (1978) Utilization of dietary urea by chicks: Japan. Poultry Sci., 15: 163-169.

18) Okumura, J., H. Tanaka and T. Muramatsu (1979) Incorporation of ${ }^{15} \mathrm{~N}$-urea in chicks: Japan. Poultry Sci., 16: 45-48. 


\title{
ニワトリヒナにおける飼料尿素及びクエン酸 2 アンモニウムの 成長促進効果について
}

\author{
奥 村 純 沛・木 野 勝 敏 \\ 名古屋大学農学部 名古屋市 464
}

\section{体内の可欠アミノ酸合成に用いられる窒素の供給源と}

して尿素, クェン酸 2 アンモニウム (DAC) といった非 蛋白態窒素化合物の利用が，鷄に扰いて報告されてい る。この尿素, DAC と対照区としてのL-グルタミン酸 を, 飼料に段階的に添加し, これら窒素化合物の成長促 進効果について調べた。

白色レグホーン種雄ヒナに 8 日龃から18日齢までの 10 日間，実験飼料を水とともに自由摄取させ，その間の

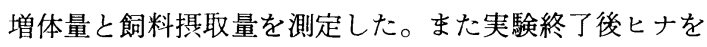
屠殺し，体組成を測定して実験期間中の窒素及びェネル ギーの蓄積について調べた。実験飼料は，それぞれのア ミ，酸要求量を充たした必須つミ/酸混合物のみを窒素 源とする基礎飼料と，これに $3.17 ， 6.35 ， 9.52 ， 12.69$ 及び 15.87 ( $\mathrm{gN} / \mathrm{kg}$ 飼料)の 5 レベルで尿素, DAC, グ ルタミン酸を各々添加した飼料の全 16 種類の飼料を用
いだ。

尿素は, 6.35 ( $\mathrm{gN} / \mathrm{kg}$ 飼料) までは添加レベルの上昇 に伴い, 体重, 窒素の蓄積量は増加するが, それ以上に 添加しても改善されなからた。束た全ての添加レベル で，その効果はグルタミン酸と比較して有意に低い值を 示した。DAC は，6.35 ( $\mathrm{gN} / \mathrm{kg}$ 飼料) までは添加レべ ルの上昇に伴い体重, 窒素の蓄積量は增加したが, それ 以上に添加すると減少した。增体重では $3.17(\mathrm{gN} / \mathrm{kg}$ 飼 料)の時に, 窒素の蓄積量では $3.17,6.35(\mathrm{gN} / \mathrm{kg}$ 飼 料) の時に,グルタミン酸と比較してほぼ同等の効果を 得たが，それ以上のレベルでは有意に低かった。窒素の 蓄積量の結果から最大值を与えるこれら窒素化合物のレ ベル $(\mathrm{gN} / \mathrm{kg}$ 飼料)を算出すると, 尿素では 6.13 以上, DAC, グルタミン酸では $6.27,11.3$ となった。

(家禽学会誌，21，49～56, 1984) 